\title{
Applying STEEPLE to course and curriculum design
}

\author{
Peter Colin Kelly \\ The School of Business and Computer Science, Trinidad and Tobago
}

\begin{abstract}
When it comes to course design in Higher Education, everything from learning theory and learning design theory to needs analysis and potential markets should shape our thinking. A group-based course-design task on the Post Graduate Certificate in Higher Education (PGCert. HE) at the University of Greenwich (UoG) provided the context within which my colleagues and I were able to bring a key aspect of our professional experience and expertise to course development. Our business background and an interest in strategic modelling in business led us to adopt the 'STEEPLE' model - an extension of the 'PEST' and 'PESTLE' models that preceded it - which is used in strategic decision-making in business worldwide.
\end{abstract}

Keywords: STEEPLE; strategy; environment; course/curricula design.

\section{Introduction}

I lecture Business Management courses to undergraduate students pursuing general and specific degrees in business management at a partner institution of the University of Greenwich (UoG) in Trinidad and Tobago; it is in this context that my colleagues and I found ourselves working towards the PGCert HE and the course design task within it. Putting aside the continuing debates about the merits and demerits of marketisation in higher education $(\mathrm{HE})$ and the fractious arguments related to whether business practices suit HE provision, I believe that strategic modelling like this has a role to play in ensuring that courses, curricula and, indeed, entire programmes of study produce graduates who can take their rightful places in the world of work in the twenty-first century. This paper will demonstrate how the 'STEEPLE' model can be applied to enhance HE course and curriculum design.

The STEEPLE model is the latest version of a strategising tool that has evolved over the years, with adjustment whenever thinkers on the subject recognised and added a new aspect of the business environment to it. The acronym itself has accordingly evolved from 'PEST', to 'SLEPT', to 'PESTLE', to 'STEEPLE', to reflect these gradual additions. It is unclear who devised this model, or when, but it gained popularity from around the middle of the twentieth century and has been a fixture in business strategic decision-making ever since.

'STEEPLE' stands for Socio-cultural, Technological, Economic, Ecological, Political, Legal and Ethical. These are the seven 'environments' within which any organisation (a university being no exception) must inevitably function. A thorough understanding of each of these environments is therefore critical to developing appropriate courses and curricula. 


\section{Applying STEEPLE to HE course and curriculum design}

All organisations, including higher education providers (HEPs), must continually engage in strategising if they are to survive in a competitive environment. STEEPLE is one of many models that help decision-makers to develop and pursue their strategies systematically and HEPs have used it for years, though always from a marketing perspective - i.e. when seeing the institution as a business selling a range of products (their academic programmes) and competing with other such institutions for customers (students). I have not, in my research, come across any cases where it has been employed to assist in designing courses/modules and curricula. Though neither a course nor a curriculum design model itself, STEEPLE can be very useful in supporting those models which are - so as to achieve design of the most appropriate courses and curricula.

According to Shaw (2002) "continuous environmental scanning" and an "ability to anticipate changes in the future" are crucial for designing any curriculum. Beetham (2012, p. 3) seems to mirror these sentiments when she says: "The ultimate goal has always been to enhance the curriculum offer, making it more responsive to new markets and needs, more sustainably delivered, more flexible, and more attuned to the capabilities required by graduates in the $21^{\text {st }}$ century". If curricula are indeed to be more responsive and flexible so that they can be more attuned to the ever-changing demands of society, then environmental scanning is indispensable - and the STEEPLE model can help to do it. 'Environment' in this context may be defined as all those factors and conditions that influence how people and organisations function. 'To scan one's environment' would therefore constitute close critical examination of any factors which impact upon one's operations.

Warren (2016) broadly classifies curriculum models as being either 'product' or 'process'. Knight (2001) and Hussey and Smith (2003) regard the former to be rigid and believe a curriculum model should be more flexible. So, since environments aren't static but quite dynamic, and since courses and curricula need to be adjusted accordingly, STEEPLE, as an analytical tool, may better suit a 'process' model.

As tertiary-level educators, we have objectives for our students that go beyond just ensuring that they 'land a good job', yet graduate employability will always be of paramount concern to us; our courses and curricula must therefore be shaped with that in mind. Lists of graduate attributes (those characteristics, skills and sets of knowledge that graduates are expected to possess upon completion of their respective programmes) now inform the student development policies and strategies of all HEPs. Gratton (2011) outlined five forces shaping the future of work:

1. Technological developments

2. Globalisation

3. Demographic changes

4. Societal trends

5. Low-carbon developments

Her list includes at least three of the seven environments contained in STEEPLE: the sociocultural, the technological and the ecological.

In the following section, I shall show how each of these environments can, and do, relate to 
the process of course and curriculum design and how my group scanned these environments as we worked on our project. It is vital both to acknowledge the overlaps between environments and to recognise how important those overlaps are.

\section{The Seven Environments}

\section{Socio-cultural}

The socio-cultural environment includes all factors relating to demographics, such as the size, structure and rate of growth of population and such things as traditions, cultural diversity and levels of education. Beetham $(2012$, p. 8) sees the "growth in the numbers of part-time, work-based learners... along with a wider range of approaches to study (flexible, part-time, online, etc.)" as factors that cannot be ignored when designing courses and curricula. For instance, the quantum of flexibility that one would include in one's curriculum would, to some extent, be influenced by such things as the ratio of work-based learners to full-time learners or the particular methods of study that are offered to, and preferred by, the students.

We are also witnessing a greater movement of people across international boundaries for the purpose of employment or study, or both, than ever before in our history; a migration which has already created many cosmopolitan societies around the world. This, no doubt, would have been one of the things that Gratton (2011) alluded to when she spoke of 'globalisation' as being one of the factors shaping the future of work. The fact that many HEPs now offer distant learning programmes, whereby students from any part of the world can pursue courses of study in other countries without actually leaving their own, adds to that globalisation phenomenon. The cultural diversity of one's student intake must therefore also be considered. This my group certainly took into account in designing our course for the mock validation panel. The course was culinary-based and sought to draw on the ethnic and cultural diversity of Trinidad and Tobago and to cater to such diversity among our students. According to Hockings (2010, p. 47), a student-focused approach to course design and delivery needs to be inclusive, so as to accommodate the cross-cultural nature of one's student population. It must aim to "anticipate, recognise and provide for individuals' specific physical, cultural, academic and pastoral needs." This can be done effectively only after a thorough scanning of one's socio-cultural environment.

\section{Technological}

When scanning one's technological environment, one would take into account the kinds and levels of technology available, their costs, their applicability to one's own context, their rate of turnover and so on. For a tertiary-level education institution, the most relevant category would be information and communication technology (ICT) and the two most common contexts to which it is applied are technology enhanced learning (TEL) and virtual learning environments (VLEs).

A distinction must be made here between technology infusion and technology integration, as the difference between the two has significant implications for TEL. The Higher Education Academy (HEA) of the UK states that, among other interpretations, the term 'TEL' "can also be used to refer to... learning with technology rather than just through technology." The infusion of technology in schools refers to teachers' and students' simply using technology to present and transmit ideas and information, whilst the integration of technology is about engaging students with those ideas, the technology itself being an integral part of the 
experience. In other words, the technology must help to support and advance the pedagogy. In developing our course and its accompanying curriculum for our mock validation, therefore, my colleagues and I had to have a clear and concrete rationale for any technology that we proposed to use. According to Hos-McGrane (2012), until and unless schools have questioned and identified their reasons for using technology, they have not gone beyond simply infusing the technology. As the name implies, TEL is meant to give students a higherquality learning experience.

If technology is indeed meant to enhance learning and the overall student experience, then courses need to be conceptualised and designed, and curricula developed, so as to have a synergic relationship with the prevailing technology. Beetham and Sharpe (2013), from a purely cognitivist standpoint, believe that no technological development has actually changed the fundamental capacities of human beings to learn. What technological advances have done, however, is to change, profoundly, "how ideas and practices are communicated, and what it means to be a knowledgeable or capable person" (p. 4). They argue that, owing to the fact that these technologies have significant impact upon the nature of knowledge in today's society, they also, by extension, have impact upon the nature of learning.

From a marketing perspective, the effect of technological advances is that they shorten product life cycles as consumers become drawn to the next new thing. Such a consideration is also applicable to course design, as course developers should take into account how relevant a particular curriculum will be in the next five to ten years, or even less, with respect to the technology being integrated into it. Such consideration is even more acute when the particular technology is itself the curriculum - i.e., a technology that graduates need to master for their intended profession/career.

\section{Economic}

The economic environment comprises all micro- and macro-economic variables, including interest rates, currency exchange rates, unemployment rates, inflation rates and GDP growth rates. Each one of these, inter alia, is very significant to a course or curriculum designer. The level of interest rates may affect students' ability to source loans to finance their education; foreign exchange rates may affect the intake of foreign students; inflation rates may affect how an institution prices its courses; and the general economic climate will certainly affect the demand for programmes offered.

The structure of an economy and the direction in which it is headed will inform the kind of graduate attributes that employers will seek and the particular skills they will want graduates to possess. This brings us right back to the issue of graduate employability that I touched on earlier. Faculties would need to design courses to complement and support the structure and growth of an economy. For instance, if an economy is essentially agrarian, then a number of agriculture-based courses, from the business of agriculture to the actual cultivation of crops, will need to be developed. Likewise, if an economy is based on tourism, then courses will need to be developed to satisfy the human resources needs of that sector. And, as these sectors change in one way or another, adjustments to courses and curricula will need to be made accordingly, even to the point of discontinuing some courses and introducing new ones.

Given the ever-increasing importance of human capital to macro-economic growth and development, Lees (2002) recognises the need for HEPs to place greater emphasis on the 
employability of graduates. It would be virtually impossible to attempt to embed some employability dimensions into any curriculum without first diligently scanning the economic environment. Gedye and Ivaldi (2016) outline seven steps to enhancing student employability. Numbers two and three are, respectively, 'enable professional work experience' and 'involve employers', neither of which can be effectively achieved without an adequate examination of the economic environment. With respect to involving employers, HEPs would first - before they can compile their lists of graduate attributes - need to consult with various employers' associations, chambers of commerce and government departments to determine exactly what employers are looking for in their employees. As far as enabling work experience is concerned, some programmes even demand a certain amount of practical learning and development in the workplace. For instance, students pursuing their degrees in pharmacology are usually encouraged by their faculty to seek vacation jobs in pharmacies and hospital dispensaries during their long summer break. Nowadays, it is also being increasingly recommended across all faculties that more opportunities be made available for a greater number of full-time students to gain some sort of work experience before actually graduating. Of course, the extent to which this is feasible would, in great measure, depend on the state of the economy at any given time.

\section{Ecological}

The ecological environment is extremely broad and comprises all physical surroundings, inclusive of their flora and fauna. It can also be taken to include the non-physical, such as climatic conditions. Generally, a faculty would not need to consider this environment when designing a course unless, and quite naturally, the course were directly related to some aspect of the ecology, such as environmental engineering or marine biology. Nevertheless, there can be some connection with other environments, such as the legal (with respect to environment protection laws) and the technological (as it may relate to issues like energysaving technology).

\section{Political}

The political environment includes, and is influenced by, such things as political stability, political ideology and philosophy, political awareness and freedom amongst the electorate (if there is an electorate!), government policies and diplomatic relations with other countries. Some of these factors can also easily change with a change of government.

One of the things that course and curriculum designers would certainly be looking at is the set of government policies with respect to $\mathrm{HE}$, especially those that deal with scholarships and other forms of funding for specific courses and programmes. Some courses are approved for funding whilst others are not. A faculty would therefore need to consider the specific criteria that determine the category into which any given course may lie. This could be significant for a number of reasons, including influencing the number of students who may enrol for a particular course. State funding, or lack thereof, was certainly one of the things that my group considered when designing our course and here was a typical example of how one environment could have impact on another. Owing to the economic downturn and decline in state revenues in our country, the government took the decision to reduce significantly its annual expenditure on tertiary academic programmes. We thus knew we had to come up with a course that would still attract the requisite number of students even though state funding was no longer available. 
Some political developments can have very far-reaching effects on a society. As a case in point: Brexit. It would not be unfair to say that Brexit has caused a bit of a maelstrom on Britain's socio-political landscape. Every facet of life in the UK has been and will be affected by it. UK HEPs are particularly concerned over its possible repercussions for them. Richard Black, writing in the Telegraph (2017), says that what people are most worried about as far as Brexit and $\mathrm{HE}$ in the UK are concerned is the potential impact on funding, student numbers, exchange programmes and the quality of teaching and research collaboration. Student numbers and teaching and research collaboration are perhaps the two areas of deepest concern. University World News (2017) reports that the number of EU students applying to British universities in this current academic year fell by $7 \%$, the first decrease in a decade. EU workers make up $12 \%$ of all UK universities' staff and $16 \%$ of their researchers are from the EU. Depending on the final terms and conditions of Brexit currently being negotiated between the UK and the EU, UK universities could lose out on some of this talent.

As to how all of this will affect the actual designing and development of courses and curricula at UK universities and colleges remains to be seen. We can be sure, however, that these activities will also be affected and that there will be implications globally - and therefore for institutions such as my own in Trinidad and Tobago, which partners with the University of Greenwich in the UK.

\section{Legal}

When scanning the legal environment, a university will look at all the laws and regulations that directly (or even indirectly) affect it. Immigration laws, especially those pertaining to foreign student visas, laws governing local student quotas and laws relating to minority student enrolment are just a few examples. Course designers must also consider regulatory bodies and accreditation boards, to ensure that their courses satisfy all the necessary criteria for approval. There may yet be some changes to certain regulations as a result of Brexit and HEPs in the UK will have to make the adjustments accordingly. Who knows?

\section{Ethical}

'Ethics' derives from the Greek word 'ethikos', which means 'custom' or 'character'. Broadly speaking, therefore, ethics may refer to human character and conduct and one's ethical environment would include all the beliefs, norms and values that help to shape that character and conduct. (Note the overlap between the ethical and socio-cultural environments.) But just how does the ethical environment influence course and/or curriculum design and how should academics deal with it?

Where course and curriculum development are concerned, Morgan and Houghton (2011) recommend an approach that "places the student at the heart of the design process" (p. 11) and embeds such principles that render it "anticipatory, flexible, accountable, collaborative, transparent and equitable" (pp. 12-13; Italics mine). The latter two speak directly to ethics. Warren (2016) cites Grundy (1987) and Cornbleth (1990), who came up with a typology for curriculum that classifies it as 'product', 'process' and 'praxis'. With the latter, there is an emphasis on 'raising students' awareness of dehumanising, inequitable and undemocratic social practices and institutions and developing more egalitarian visions of society" (p. 14).

The challenge for course and curriculum designers is not how to proceed with their curricula in an ethical manner; that's easy enough. The question is: How do we use our courses to 
raise our students' awareness of social injustices and develop in them more egalitarian visions of society? This might be easier and more natural for a course in philosophy perhaps, but how does one embed it in other disciplines? Each professional body, whether of accountants, attorneys or architects, has a code of ethics for its members and, I guess, one simply has to look to these codes to know just what needs to be included (explicitly or implicitly) in any course.

\section{Conclusion}

These seven different interpretations of environment really constitute the overall external environment of any university or even of any faculty. Of course, in designing courses and curricula, one also needs to scan one's internal environment, which includes a host of different things as well - from the physical infrastructure and the various facilities that go with it, to the human resources, ethos of the organisation and the systems and processes in place.

STEEPLE is one of many strategy models that a HEP can employ. Even so, it's usually used in conjunction with other strategy models to increase the effectiveness of one's decisionmaking. When used to support pedagogic theory and subject content considerations, it can provide an invaluable way of ensuring that key aspects are not ignored at the planning stage of any course or curriculum.

\section{Reference list}

Beetham, H. (2012) Institutional Approaches to Curriculum Design: Final Synthesis Report, November 2012. Available at:

http://jiscdesignstudio.pbworks.com/w/file/fetch/61216296/JISC\%20Curriculum\%20Design\% 20Final\%20Synthesis\%20i1.pdf (Accessed: 10 June 2017).

Beetham, H. and Sharpe, R. (2013) Rethinking Pedagogy for a Digital Age: Designing for $21^{\text {st }}$ century learning. Abingdon: Routledge.

Black, R. (2017) How will Brexit affect British universities and will EU students still be able to study in the UK? Available at: www.telegraph.co.uk/education/0/will-brexit-impact-britishuniversities/ (Accessed: 10 July 2017).

Gedye, S. and Ivaldi, F. (2016) 7 Steps to: Enhancing Student Employability, 7 Steps Series, Teaching and Learning Support (TLS). Plymouth: University of Plymouth.

Gratton, L. (2011) The Future of Work. London Business School. Available at: http://innovation.london.edu/resource/59/index.html. (Accessed: 29 June 2017).

Hockings, C. (2010) Inclusive Learning and Teaching in Higher Education: A synthesis of research. York: Higher Education Academy. Available at:

https://www.heacademy.ac.uk/resources/detail/resources/detail/evidencenet/Inclusive learni ng and teaching in higher education (Accessed: 02 July 2017). 
Hos-McGrane, M. (2012) Tech Transformation: Using Technology-v-Integrating Technology. Available at: www.maggiehosmcgrane.com/2012/10/using-technology-v-integrating.html (Accessed: 19 June 2017).

Hussey, T. and Smith, P. (2003) 'The trouble with learning outcomes.' Active Learning in Higher Education, 3 (2).

Knight, P. (2002) Being a Teacher in Higher Education. Buckingham: SRHE/OU.

Lees, D. (2002) Graduate Employability: A Literature Review. Available at: www.qualityresearchinternational.com/esecttools/esectpubs/leeslitreview.pdf (Accessed: 16 June 2017).

Morgan, H. and Houghton, A-M (2011) Inclusive Curriculum Design in Higher Education: Considerations for effective practice across and within subject areas. York: Higher Education Academy. Available at:

www.heacademy.ac.uk/resources/detail/inclusion/Disability/Inclusive curriculum design in higher education (Accessed: 10 June 2017).

Shaw, M. (2002) Contexts for Curriculum Design: working with external pressures. York: Higher Education Academy. Available at: https://www.heacademy.ac.uk/individuals/studentsuccess/toolkits/TEL (Accessed: 10 June 2017).

University World News (Issue \# 485, Dec.2017) UK universities must face Brexit drivers and outcomes.

Available at: www.universityworldnews.com/article.php?story=20171202052301834 (Accessed: 30 January 2018).

Warren, D. (2016) 'Course and learning design and evaluation.' In: Pokorny and Warren (eds.) Enhancing Teaching Practice in Higher Education. London: Sage, 11-46. 